\title{
Moral and Social Values in the Novel Si Anak Pintar by TereLiye and Its Usefulness as Reading Materials at SMA Dwitunggal Tanjungmorawa
}

\author{
Puteri Sion Aritonang ${ }^{1, *}$ Oky Fardian Gafari ${ }^{2}$ Elly Prihasti Wuriyani ${ }^{3}$ \\ 1,2,3 Indonesian Language and Literature Education Sudy Program, Universitas Negeri Medan, Indonesia \\ "Corresponding Author. Email : puterisionaritonang@gmail.com
}

\begin{abstract}
This study aims to analysis moral values (individual, social, religious), analyze social values (love, responsibility and harmony in life) and analyze the usefulness of the results of study the novel Si Anak Pintar by Tere Liye. This research produces a product in the form of reading material, is namely an enrichment book at SMA Dwitunggal Tanjungmorawa. The research method used is descriptive qualitative. The results of this study are 1) Description of individual moral values, social moral and religious moral are described based on quotes taken from the novel Si Anak Pintar by Tere Liye, 2) Descriptions of social values of love, responsibility and harmony in life are described based on quotes taken from the novel Si Anak Pintar by Tere Liye, 3) The usefulness of the study as literary reading material at SMA Dwitunggal Tanjungmorawa has a very good criteria as a suplement book for Indonesian language learning with an average of $85.5 \%$. The results of material expert validation including aspects of the feasibility of reading materials get an average of $82.81 \%$ in the very good category, the feasibility of presenting in reading materials gets an average of $85.5 \%$ in the very good category and language assessments get an average of $82 \%$ with very good category. The results of the validation of design experts get an average of $90 \%$ with a very good category. It was concluded that this reading material could be a suplement book for Indonesian learning.
\end{abstract}

Keywords: Reading Material, Values, Moral, Social, Novel.

\section{INTRODUCTION}

Literature can be said as a reflection of human life in which there are moral and social values Literature is a miniature of human life that tells various problems, moral conditions, aesthetics, and things related to human association (Kosasih 2003:195). Fiction literary works to tell various problems of human life accompanied by interactions with oneself and God (Nurgiyantoro, 2005). Novel is a type of prose fiction that has a role in giving messages in human life. This is because the themes in the novel often raise problems in human life. Novels can be also a source of student reading in the library. Through novels, students can take the good things in the novel such as religious, cultural, social and educational values.

Moral values are very important and the inculcation of these values should not only be in the subjects of Citizenship Education and Religious Education but in other subjects as well. In addition, school programs and organizations can help the role of teachers as role models in the formation of moral values in students (Poni, 2017).
Based on the explanation of the phenomenon of moral values, it can be concluded that the decline in moral values and the high number of juvenile delinquency cases make moral values very important to be taught to students in all subjects. School programs and organizations can help the teacher's role as an example in shaping moral values. In addition to the important moral values to be taught, social values also have an important role. Social media can be a source of students' deviant and immoral moral behavior. (Budayati MZ, 2012 (2017). The problems in students are the weaker social integrity, reduced manners of social life, ethics in schools, society and makes a lot of negative behavior. (Arifin, 2017: 27 (2020). Based on an explanation of the phenomenon moral values, it was concluded that social values also have an important role in shaping the behavior of students who have superior character and personality.

Literature can be a solution in still moral and social values in students. Moral values in literary works are basically conveyed by the author to be able to educate 
and regulate human behavior to be good. Moral values are expected to be able to bring up positive values for readers who are sensitive to social life problems and encourage good behavior. This is makes social values a solution in learning literature. (Tye, 2019). The results of observations in the library of SMA Dwitunggal Tanjungmorawa and an interview with an Indonesian language teacher, Mrs. Listiawati, found that the availability of literary reading materials in the library was minimal. The lack of reading literature for students is an obstacle in learning literature. The low role of reading materials has an impact on not achieving the expected competencies. This can be seen from the achievement of student competence in analyzing and appreciating novels under the minimum completeness criteria of 75 , it makes literary reading materials and literature learning have a strong relationship to achieve the success of literary learning in schools (Made Kerta Adhi (2015) the list of reading materials for SD/MI, SMP/MTS and SMA/MA made by the National Education Standards Agency (BSNP) 2019 is still limited. It was recorded that for $\mathrm{SD} / \mathrm{MI}$ the number of reading materials is 73 , for SMP/MTS as much as 70 and for There are 80 SMA/MA, consisting of illustrated stories, poetry, drama, short stories and novels. Literature can be the right solution to solve the problems of the younger generation whose behavior does not reflect noble values and local wisdom (Qomariyah, et al (2019, in the journal RETORIKA: Journal of Language, Literature, and Teaching, Volume 12, Number 1.95). The choice of the novel Si Anak Pintar as reading material for SMA Dwitunggal Tanjungmorawa, because this novel has the privilege of being a Best Seller novel. The theme in this novel is also about the simplicity of life, the selection of language styles that are easy to understand makes this novel suitable for reading material for high school students Dwitunggal Tanjungmorawa, because this novel has many moral and social values.

The problems that will be studied in this research can be formulated: 1) how is the description of moral values in the novel Si Anak Pintar by Tere Liye?, 2) how is the description of social values in the novel Si Anak Pintar by Tere Liye?, 3) how is the usefulness of the results of the study Tere Liye's novel Si Anak Pintar as literary reading material in the form of an enrichment book at SMA Dwitunggal Tanjungmorawa?

The operational in this study is as follows:

\section{a. The Nature of Moral Values}

According to Bertens (2007:4) moral comes from the Latin mos (plural: mores) which means custom, habit.
Etymologically, the word moral is equivalent to ethics and both have the meaning of custom. In connection with this, Budiningsih (2008:24) believe that morals always refer to the good and bad of humans. Darajat in Ernawati (2005:21) also explains that, Morals are ways, customs, habits, morals, behavior, decency, in the form of actual values for humans that are in accordance with the standards (values) of society, which arise from the heart not from external coercion accompanied by a sense of responsibility. on the behavior (the action). Based on the opinions of the experts above, it can be concluded that morals are ways, habits, morals related to human actions in their actions and control in behaving.

\section{b. The Nature of Social Values}

Social values that are trusted by the community, regarding things that was considered good and bad by the community. Social values are also a guide for humans to behave and determine whether a person is good or bad in acting and thinking in social life. Social values regulate the norms of human relations who live as social beings and in groups. Raven in Zubaedi, 2005: 12 also argues that social values are a set of individual attitudes that are valued as truth and used as standards of behavior in order to obtain a democratic and harmonious society. Based on the description above, it can be concluded that social values have the aim of regulating human behavior in social life.

\section{c. Understanding Novels}

Nurgiyantoro (2018:11) states that the novel is a literary work that expresses deeper aspects of humanity and was presented subtly. Novel is a literary work that contains various events experienced by characters systematically by presenting the most complete elements of the story. Semi (2000:32) argues, the novel is a work of fiction that expresses a deeper aspect of humanity and was presented subtly. The novel talks about human life about the description of the relationship between humans and their environment. As a literary work, novels are created so that readers can gain insight into human life, besides that is novels can also be used as public reading material. In literary works, life occurs according to the background of the author and the attitude of the author. 


\section{METHOD}

Descriptive method is a research method that is carried out based on facts or phenomena that are empirically alive in the speaker, so that the resulting exposure is as it is. Qualitative research requires planning and research design. Plans are sudden and develop according to findings in the field. The changed design is circular due to the purposive sampling, data collection and analysis is carried out simultaneously and is an interactive step, not separate.

\section{RESULTS AND DISCUSSION}

\subsection{Individual Moral Values}

Individual morals are morals related to human relations with themselves. This individual moral is the basis of actions and instructions in life. Individual morals consist of: honest, humble, brave, working hard, keeping promises, fair, wise, kind, respectful and appreciative. In the novel Si Anak Pintar by Tere Liye, individual moral values are only honest, humble and kind.

Burlian and I looked at each other.If only we could be as easy as Raju forging a permit. But we quickly pushed that thought away. That's a dangerous idea.If Mamak finds out, the punishment will be very severe. (Tere Liye, 2020:37).

In this quote Pukat and Burlian experience inner conflict with themselves. Inner conflict is the conflict of the human soul in the face of an event. The Big Indonesian Dictionary states the term inner conflict which means conflict caused by the existence of two or more conflicting ideas or desires that dominate so that it affects behavior. In line with that, Alwi, et al (2005: 587) argue that conflict is caused by the existence of two or more ideas, or conflicting desires to control oneself so that it affects behavior.

\section{- Humble}

Humility is an attitude that does not boast. In Tere Liye's novel Si Anak Pintar, the value of humility is reflected in the characters Bapak, Pukat and Burlian, along with their quotes. "It's true what Mr. Bin said at school. The stalk of rice, the fuller it is, the more bends down." Burlian pointed at the rice stalks. (Tere Liye, 2020: 318).

"Yes." Father pointed to one of the rice stalks. "The fuller the more bent down, it also means you always not only feel can, can, and can. More important than that was you can always feel. The day after tomorrow, if you have migrated to faraway cities, across islands, you will see lots of smart people, great people. They always say, 'Yes, we can', or 'Yes, together we can', and other sophisticated sentences. Unfortunately, among so many great people, very few can empathize, feel, and be filled with the spirit of genuine kindness." (Tere Liye, 2020: 319).

In this quote, there was a conversation between Burlian, Bapak and Pukat who are discussing humility. Lickona (2004) says that humility is a virtue that is considered the basis of the overall moral life. Humility is one of the most basic and important self-characteristics to be grown, trained, and accustomed to students so that they can be applied in everyday life. Humility is needed to be acquired by other virtues because it makes individuals realize their imperfections, dare to admit mistakes and take responsibility for what they have done, and make individuals try to become better people. However, behavior that shows humility among teenagers is still lacking. In addition, according to the Big Indonesian Dictionary, the term humble means that it is not arrogant or arrogant.

\section{- Good}

The message about kindness was conveyed by Mr. to Pukat. The Pukat who remembers the message doesn't realize it yet but the message will be a clue to the Pukat when he grows up. Your message can be seen as follows.

I'm busy chewing fried prawns. The day after tomorrow, when time took us to leave the village, whether it was continuing school, job demands, or just an adventure, I realized that your words were true. There are many small kindnesses that are lost one by one in this life. Moreover, the bigger ones. (Tere Liye, 2020:241).

In this quote Pukat remembers the advice that was conveyed by Mr. The Big Indonesian Dictionary states that advice is a good teaching or lesson, a good suggestion (hint, warning, reprimand). The message that Pukat remembers as an adult about small kindnesses slowly begins to fade when they live far from the village. The advice that Mr. gave to Pukat was about goodness. Pukat recalled when he was in the village, there were lots of small kindnesses he could meet. The message from Mr. made Pukat better understand how important the advice he had received from Mr. This shows that the advice that you gave to Pukat will be a message that Pukat will remember and follow.

\subsection{Social Values (Compassion) \\ - Social Value of Compassion (Devotion)}

Devotion was a process that is carried out by someone in an activity sincerely. The devotion in this quote can be 
seen in the character of Pak Bin. Pak Bin has devoted himself to being a teacher in the village for almost 25 years. Pak Bin's dedication can be seen in the following quote.

... Twenty-five years Pak Bin has been a teacher at the school, almost all of the village children and adults have been Pak Bin's students. A long service, and he does it with pleasure. He always told us never to stop believing. School will be the path of a better future for us. There are only two things we don't like about Pak Bin, his discipline and his homework. (Tere Liye, 2020:61).

This quote shows how long Pak Bin has served as a teacher in the village. Pak Bin has been a teacher in the village for 25 years. Devotion is an act that someone does sincerely. Pak Bin devotes himself to being a teacher in the village and works with a happy heart. Pak Bin always hopes that the children he teaches can have a bright future by continuing to study and attend school.

\section{- $\quad$ Social Value of Compassion (Help)}

Helping is an attitude of helping each other to ease the burden/difficulty of others by doing something. The father figure shows a helping attitude through his actions to save Raju. This helpful attitude can be seen in the following sentences.

"It's two in the morning." Father finally sighed, looking at the clock on the wall. "It will take another three hours at least for the surroundings to look bright enough. Pendi, Juha, and the others, you take out all the village bamboo lantings, ropes, whatever. O Allah, if the water level continues to increase, even if it is brightly lit, it is still impossible for us to reach the lake. Lest the lake has been destroyed. You hear, get ready the end of the village. As soon as you can see each other's arms, when the first light of the sun arrives, when the surroundings begin to appear, immediately launch a bamboo lanting towards the lagoon. Do whatever it takes to save Raju. Understand!" (Liye Tere, 2020: 121).

Helping is an attitude of helping each other to ease the burden/difficulty of others by doing something. The father figure shows a helping attitude through his actions to save Raju. This helpful attitude can be seen in the following sentences.

In this quote you can see that you are trying to help Raju. According to Hogg \& Vaugha 2002, helping is an action that benefits others. The helpful attitude shown by you is part of the desire that Pukat conveyed to you. The seines are worried about Raju's condition in the lake and in a state of great flood. You can see what you've done for help when Pendi and Juha were also asked by you to prepare all the tools to save Raju.

\section{- Social Value of Compassion (Caring)}

Caring is a human attitude in general. The attitude of caring is close to empathy for fellow humans, this can be seen when giving good treatment to fellow humans. Pak Bin's character as a teacher shows his caring attitude towards Raju. Pak Bin's concern can be seen in the following sentence.

.. "Alright, you guys should thanks to Raju for these pastries. Because today, we celebrate two whole months Raju is never absent again, and he always comes on time. Great, right? No more fake letters, saying you have tinea versicolor, stomach ache, no more skipping school. So let's all give a round of applause for Raju." (Tere Liye, 2020:62).

This quote shows Pak Bin's care for Raju. Yaumi (2018:77) argues that caring is feeling the worries of someone else or something. Someone who has a sense of caring for others will give attention to others. In line with that, the Big Indonesian Dictionary also states the term caring is a matter of very caring; caring attitude (concern).

\subsection{Social Values (Responsibility)}

Responsibility is the state of being obliged to bear everything. Zubaedi (2005:13) divides responsibilities into three, namely the value of belonging, discipline, and empathy. In the novel Si Anak Pintar by Tere Liye, the social value of responsibility only contains the values of discipline and empathy.

- Value of Social Responsibility (Discipline)

Discipline is a teaching and learning process that leads to order and self-control. Discipline can be seen in Pak Bin's character who explains the rules during the exam.

"You have pens in your bag, two in fact. You see Lamsari next to you also has a spare two ballpoints. But baby, rules are rules, Seine. We are appreciated not because we are scary, fierce, let alone powerful. We are rewarded for enforcing the rules of the game. You already know the risks yourself." Mr. Bin smiled faintly, waving his hand. (Tere Liye, 2020: 125).

The Big Indonesian Dictionary states that the term discipline is obedience (compliance) to regulations (order and so on). Pak Bin's character makes rules so that his students are disciplined, namely they are not allowed to borrow pens while the exam is in progress. Pak Bin reexplained the rule when he saw Pukat who was confused when his pen could not be used and did not have a spare pen. This is done by Mr. Bin. 
- Value of Social Responsibility (Empathy)

Empathy means being able to feel a situation experienced by another person. Pak Bin's character shows empathy for Pukat, who was sad about Raju's condition. Pak Bin's empathetic attitude can be seen in the following quote.

"Pray, Seine. Hopefully Raju can last for three hours. Hopefully the lagoon will stay strong against the river water."Mr. Bin stroked my hair. (Tere Liye, 2020: 122).

In this quote, Pak Bin is seen calming Pukat. The Big Indonesian Dictionary states the term empathy is a mental state that makes a person feel or identify himself in the same state of feeling or thought with other people or groups.Pak Bin's empathy was shown when he tried to make Pukat feel calm. Pak Bin tells Pukat to keep praying and that Raju is safe.

\subsection{Social Values (Life Harmony)}

\section{- Social Value of Harmony of Life (Justice)}

Zuriah (2008:98) argues that justice is a state of avoiding taking sides. Justice is also a collaboration to produce an organically unified society so that every community has the same opportunity to grow and learn according to their abilities. The quote on the social value of harmony of life (justice) was seen in the character Lamsari who was fair when Pukat and Raju fight.

"The important thing is that this image is deleted. I also told Raju earlier that it's not good to make fun of your best friend." (Tere Liye, 2020: 83).

In this quote, it can be seen that Lamsari's character does not side with his friends who are fighting. In accordance with Zuriah's opinion, Lamsari's attitude is not partial to anyone. Instead, he hoped that the two friends would reconcile and not make fun of each other. Lamsari's fair attitude to Pukat and Raju had an impact so that the two friends did not fight and hurt each other.

\section{- Social Values of Life Harmony (Cooperation)}

Samani (2012:118) argues that cooperation is an attitude or action of someone who wants to work with others to achieve common goals and mutual benefits. Cooperation can be carried out by community groups. The quote on the social value of harmony of life (cooperation) is seen in the figures of Pak Bin and Pukat who work together so that Mrs. Ahmad's financial problems can be resolved.

"This idea is amazing. In addition to providing a way out for Ahmad's mother to continue selling, the shop is still open, the children can shop for necessities, ideas and at the same time train children to be honest. Let me give that understanding many times, many times, and many times for them. God willing, there will be no problems." (Liye Tere, 2020: 141).

According to Samani's opinion, cooperation is the attitude of a person with others to achieve common goals and benefits. Pak Bin and Pukat's attitude towards this quote reflects the form of cooperation. Pak Bin and Pukat helped Ibu Ahmad to open his shop. It was done by Pukat and Pak Bin to help Mrs. Ahmad's finances, who was struggling. Pak Bin and Pukat's plan is to achieve a common goal. Pukat's goal is to ease the financial burden of Mrs. Ahmad and Mr. Bin's goal to train children's honesty. It shows the desire to achieve mutual benefits through cooperation.

- $\quad$ The Benefits of Tere Liye's Novel The Smart Child by Tere Liye as Reading Material in the Form of an Enrichment Book at SMA Dwitunggal Tanjungmorawa

The usefulness of the Study Results of Tere Liye's Novel Si Anak Pintar as Reading Material in the Form of an Enrichment Book at SMA Dwitunggal Tanjungmorawa was seen from interviews and student questionnaires. The first was an interview with three Indonesian teachers at SMA Dwitunggal Tanjungmorawa about the relevance and usefulness of moral and social values in Tere Liye's novel Si Anak Pintar as reading material at SMA Dwitunggal Tanjungmorawa.

The first informant in this interview argued that literature has an important role in shaping student attitudes, especially moral and social values. The novel Si Anak Pintar by Tere Liye was chosen as a lesson because it contains good moral and social messages. He also believes that apart from textbooks, other references such as companion books are needed in learning. The second resource person in this interview gave a good opinion on the reading material in the form of an enrichment book. In the reading material in the form of an enrichment book, there is the Si Anak Pintar novel which has moral and social values contained therein. For example, the values of honesty, gratitude, and good things about a simple life. In addition, reading materials in the form of enrichment books can also be a medium in learning literature. The third resource person in this interview said that the moral and social values in the novel Si Anak Pintar can be input and examples for students when reading the novel. The characters in this novel reflect moral and social values that can make students reflect on these values. He also said that novels, poetry anthologies and short stories could be other references in literature learning. 
Based on interviews with three sources about the relevance and usefulness of moral and social values in Tere Liye's novel Si Anak Pintar as literary reading material at Dwitunggal High School, the following conclusions are obtained:

- The results of this study can be used as reading material in the form of an enrichment book. Literature has an important role in shaping student attitudes. The selection of the novel Si Anak Pintar by Tere Liye is suitable because it contains a good moral and social message. Enrichment books can be a companion book in literature learning.

- Reading material in the form of an enrichment book can be a medium in learning literature. The values contained in the novel Si Anak Pintar by Tere Liye can be a good lesson for students.

- This enrichment book can be another reference in learning literature. The values contained in the novel Si Anak Pintar can make students reflect and reflect on themselves.

\section{CONCLUSION}

The conclusions in this study are an overview of the overall research discussion which is expected to be able to answer the problem formulation that the description of individual moral values, social morals and religious morals in Tere Liye's Si Anak Pintar novel is a description of the character's behavior in doing honest, humble, kind, mutual attitudes. work together, obey God's commands, always hope in God and always be grateful. This is the basis for the attitude of the characters in the novel Si Anak Pintar by Tere Liye.

Description of the social values of love, responsibility and harmony of life in Tere Liye's novel Si Anak Pintar in the form of a description of the character's behavior in helping, serving, caring, disciplined, empathetic, fair and cooperative. This is the basis for the attitude of the characters in the novel Si Anak Pintar by Tere Liye.

The usefulness of the results of the study of the novel Si Anak Pintar by Tere Liye as a form of student reading material in the form of an enrichment book in high school, namely being able to increase students' knowledge of prose fiction, especially novels and shape students' character through the moral and social values contained in the enrichment book material. This usefulness is supported by the results of interviews, questionnaires, and observations which state that literary reading materials in the form of enrichment books from the results of this study are appropriate as supporting textbooks with very good criteria.

\section{REFERENCES}

[1] Alwi Hasan, et al. 2005. Big Indonesian Dictionary. Jakarta : Ministry of National Education Balai Pustaka. Aminuddin, A. 2010. Science Education. Jakarta: Rieneka Cipta.

[2] Aryaningsih, et al. 2013. Development of Indonesian Literature Reading

[3] Teaching Materials and Authentic Assessment Tools for Class VII Semester I Students of SMP Negeri 8 Denpasar. Journal of Ganesha University of Education Graduate Program. Denpasar: Ganesha University of Education National Education Standards Agency 2019

[4] Baron, R.A. and Byrne, D. (2005). Social psychology. Tenth edition:volume 2. Jakarta: Erlangga. Bertens, K. 2007. Ethics. Jakarta; PT Gramedia Pustaka Budiningsih,

[5] Asri. 2008. Moral Learning Based on the Characteristics of Students and Their Culture. Jakarta: Rineka Cipta Bungin, Burhan. 2012. Qualitative Research Data Analysis. Jakarta: PT. Rajagrafindo Persada.

[6] Dharma Kesuma. 2012. Character Education Theory and Practice Studies in Schools. Bandung: PT Teen Rosdakarya

[7] Ministry of National Education, 2007. Big Indonesian Dictionary. Jakarta: Balai Pustaka.

[8] Dewi, et al. 2013. Analysis of Character Educational Values of the Novel Shoes Dahlan by Khirisna Pab Dichara and Its Relevance to Teaching School Character Education in Indonesia. Journal of Undiksa Jakarta. Volume V Endraswara,

[9] Suwardi. 2013. Sociology of Literature: Theory and Interpretation Studies, Yogyakarta: Publisher Ombak Esten,

[10] Mursal. 1987. Literature: Introduction to Theory and History, Bandung: PT Angkasa. Gordon, Thomas. 1996. Teaching Children Self-Discipline at Home and at School. Jakarta: PT Gramedia Pustaka Utama Hasanah,

[11] Uswatun. 2017. Moral Values in Sāq Al-Bambū by Sad Al-San'ūsī. Adabiyyāt: Journal of Language and Literature, Vol. I, No. 1. Hogg, M.A \& Vaughan, G.M. (2002). 
[12] Social psychology: 3th edition. London : Prentice Hall Iye, et al. 2019. Moral Values in the Main Characters in the Red Satin Novel by Brahmanto Anindito and Rie Yanti.

[13] Telaga Bahasa, Vol. 7, No. 2: 195-206 Kusnaedi. 2006. Understanding Gotong Royong. Jakarta: Rineka Cipta. Lickona,

[14] Thomas. 2004. Educating for Character, How Our Schools Can Teach Respect and Responsibility. NEW York: Bantam Books

[15] Mahayana. 2015. The Book of Literary Criticism Jakarta: The Indonesian Obor Library Foundation.

[16] Made, Kerta Adi. 2015. Authentic Assessment in Literature Learning: A Literature Review. Script. 27(2): 219

[17] Mohamad Mustari. (2011). Character Value. Yogyakarta: LaksBang PRESSindo.

[18] Moleong, Lexy J. 2012. Qualitative Research Methodology. Bandung: PT. Rosdakarya Youth.

[19] Nindhika, et al. 2018. Internalization of SocioCultural Values Through History Learning in Class X SMA Semesta Semarang for the 2017/2018 Academic Year. Indonesian Journal of History Education. 6(1), 2018: p.14-20 Nurhayati, 2008. "Moral Values in the Novel Sang Guru by Gerson Poyk: A Semiotic Review". Thesis Surakarta: UMS.

[20] Nurgiyantoro, Burhan. 2018. Theory of Fiction Studies. Yogyakarta: Gadja Mada University Press. Qomariyah, et al. 2019. The Prophetic Ethics of Surakarta Folklore: RETORICS: Journal of Language, Literature, and Its Teaching, Volume 12, Number 1: p. 94-104

[21] Pony, et al. 2017. Instilling Moral Values in Students Through the Reigious Culture Program for High School Students (Sma) Negeri 1 Tilamuta. JPs: Journal of Scientific Research and Development. Volume 02, Number 02.

[22] Pradopo, R. D. 2005, Some Literary Theories, Methods, Criticism, and Application. Yogyakarta: Student Library. Book Center of the Ministry of
National Education. 2008. Guidelines for Writing Non-Text Books. Jakarta: Book Center of the Ministry of National Education.

[23] Ratna, Nyoman Kutha. 2007. Theory, Methods, and Research Techniques. Yogyakarta: Student Library.

[24] Samani, Muchlas and Haryanto. 2012. Concepts and Models of Character Education. Bandung: Rosda.

[25] Sudarma, Momon. 2014. Sociology of Communication. Jakarta: MediaDiscourse Partners.

[26] Saptono (2011), Dimensions of Character Education, Insights, Strategies and Practical Steps. Jakarta: Erlangga.

[27] Solihatin \& Raharjo, (2009). Cooperative Learning Analysis of Social Studies Learning Model, Jakarta: Bumi Aksara. Sirait,

[28] Bistak. 2008. http:oreniffmilano.wordpress. com.2009/04/03/influence of discipline-learningenvironment-family-school-to-student-learning achievement. Sitepu, B.P. 2012. Writing Textbooks. Bandung: PT Pemuda Rosdakarya.

[29] Siswantoro.2014. Literary Research Methods. Yogyakarta: Student Library Semi, M. Atar. 2000. Literary Anatomy, Padang; Great Space.

[30] Subroto. 1992. Qualitative Research. Jakarta: Grafindo Persada Sudaryanto. 2015. Methods and Various Language Analysis Techniques. Yogyakarta: Sanata Dharma University Press

[31] Sugiyono. 2010. Educational Research Methods (Quantitative, Qualitative, and R\&D Approaches). Bandung: Alphabeta.

[32] Sugiyono. 2013. Educational Research Methods. Bandung: Alphabeta Suseno, F.M. 1987. Basic Ethics: Fundamental Issues of Moral Philosophy. Yogyakarta: Kanisius.

[33] Sukatman. 1992. "Educational Cultural Values in Indonesian Proverbs". Thesis. Malang: IKIP Postgraduate Program. Sukmadinata, Nana Syaodih. 2009. Educational Research Methods. Bandung: PT. Rosdakarya Youth. Suryaman, Mam 